\title{
Sustainable and Adaptive Re-use of the Old Industrial Buildings as Cultural Buildings in China
}

\author{
Wu Xiaoyu \\ Co. Ltd of Beijing Institute of Architectural Design, China.
}

Type of Work: Peer Reviewed.

DOl: http://dx.doi.org/10.21013/jmss.v16.n2.p1

\section{How to cite this paper:}

X., Wu. (2020). Sustainable and Adaptive Re-use of the Old Industrial Buildings as Cultural Buildings in China. IRA-International Journal of Management \& Social Sciences (ISSN 2455-2267), 16(2), 40-44. doi:http://dx.doi.org/10.21013/jmss.v16.n2.p1

(C) Institute of Research Advances.

\section{(cc) BY-NC}

This work is licensed under a Creative Commons Attribution-Non Commercial 4.0 International License subject to a proper citation to the publication source of the work.

Disclaimer: The scholarly papers as reviewed and published by the Institute of Research Advances (IRA) are the views and opinions of their respective authors and are not the views or opinions of the IRA. The IRA disclaims of any harm or loss caused due to the published content to any party.

Institute of Research Advances is an institutional publisher member of Publishers International Linking Association Inc. (PILA-CrossRef), USA. The institute is an institutional signatory to the Budapest Open Access Initiative, Hungary advocating the open-access of scientific and scholarly knowledge. The Institute is a registered content provider under Open Access Initiative Protocol for Metadata Harvesting (OA/-PMH).

The journal is indexed \& included in WorldCat Discovery Service (USA), CrossRef Metadata Search (USA), WorldCat (USA), OCLC (USA), Open J-Gate (India), EZB (Germany) Scilit (Switzerland), Airiti (China), Bielefeld Academic Search Engine (BASE) of Bielefeld University, Germany, PKP Index of Simon Fraser University, Canada. 


\section{ABSTRACT}

With the rapid expansion of the city in China, more and more old industrial buildings in cities become idle and abandoned. However, Old industrial buildings are carrying the history of a city and reflecting the urban development process so that renewal of the old industrial buildings has great value in the sense of cultural, aesthetic, ecological, economic, and sustainable development. How to reuse those buildings is worth studying. This paper, based on the principle of Adaptive Renewal and sustainable reuse, takes two typical successful cases to discuss how to reuse these old industrial buildings into culture ones in China.

Keywords: Adaptive Renewal, old industrial buildings, culture buildings, sustainable reuse

Since the 1990s, due to the adjustment of China's macroeconomic development strategy and the needs of urban development planning, some of the state-owned large and medium-sized enterprises, such as textile, machinery and heavily polluting enterprises and other related industries, have adjusted, merged, converted or relocated. This left a large number of abandoned or idle factories and warehouses. However, Old industrial buildings are carrying the history of a city and reflecting the urban development process so that renewal of the old industrial buildings has great value in the sense of cultural, aesthetic, ecological, economic, and sustainable development. How to reuse those buildings should be paid attention to related studies. Thus, this paper, based on the principle of adaptive renewal and sustainable reuse, takes two typical successful cases to discuss how to reuse these old industrial building into culture ones, which displays significance, indicating not only making the life cycle of buildings continued and the urban better developed, but also reducing the urban architecture trash burden and keeping the sustainable development of architecture.

\section{Sustainable reuse in architectural design}

In architectural design, "sustainable reuse" may cover the following features: (1) Considering the needs of social development, (2) The effective protection of the environment, (3) The prudent use of natural resources, (4) Maintaining the stable and high-speed growth of economy and employment.

Thus, in the global pursuit of sustainable development, the reuse of old industrial buildings not only saves building materials, manpower, and time but also reduces the pressure on urban transport, water and power consumption during the construction process. Meanwhile, this is an effective measure to reduce the amount of municipal waste. Currently, China's construction waste accounted for 30\% 40\% of the total amount of garbage and this ratio is much higher than the level of western developed countries. Therefore, reforming and reusing the old industrial buildings can meet sustainable development requirements.

\section{The adaptive renewal and sustainable development value of the renewal}

The adaptive renewal in architecture research means not to demolish the original buildings, but to use with slight transformation.

Generally, the renewal of the old industrial buildings not only improved the value of land use, reducing the production of construction waste, but also extended the life cycle of the building, retaining the content of the context and the psychological demands. Therefore, renewal is an effective means of 
sustainable development of the building, and this paper attempts to use it to reuse those old industrial buildings into cultural ones in China.

Sustainable development is a major issue of urban development. "Beijing Charter" pointed eco-building development goals — Revalue, Renew, Reuse, Recycle, Reduce.

According to Ye, Y. B (2005), the demolition of the building not only produces a large number of construction waste, but also causes the waste of resources. The transformation or renewal of the old industrial buildings is a typical resource recycling, the typical "turning waste into treasure", which not only meets the requirements of contemporary people, but also reduces the damage to the survival environment of the descendants. It has a realistic ecological value that concords with sustainable development.

\section{Principles for Design method in sustainable renewal of the old industries buildings}

There are normally three principles which can guide us in design methods and they can be expounded as follows:

1. Functional matching principle

When the new features replace the old function, the designer should consider the use of the original function, whether it can establish a matching relationship.

And the original function should be inherited and used.

\section{Space suitability principle}

Space suitable principle refers to the transformation of the space that needs to be suitable for visitors. To meet the requirements of the industry and place giant machines, most of the industrial buildings are large-span structure, large space scale, and even "superman" giant structure scale. (李亦哲, 郭卫宏. 2015)

After the transformation, the size should be adjusted, and it will become a suitable scale. At the same time, the old and new space should also meet each other, harmonious coexistence.

\section{Sustainable development principle}

In the process of developing the transformation plan, designers should consider the economic rationality and reduce the damage to the environment.

The reuse of old buildings is also intended to reduce the use of building materials and reduce damage to the environment. Using less input to create rich cultural and social benefits is the nature of the sustainable renewal of architecture.

\section{Successful Cases of Reconstruction and Reuse of Old Industrial Buildings in China}

How to reuse these old industrial buildings into cultural ones in China is the focus of this paper. In the following sections, we take two typical cases to discuss.

1) OCT Loft Creative Culture Park 
OCT LOFT Creative Culture Park is located in Shenzhen OCT east original industrial zone. With the development of the city, the original industrial plant, warehouse, dormitory, and other large industrial buildings were abandoned.

The old industrial district was designed and transformed by Urbanus. After that, architectural configuration and historical traces are retained, and the old industrial plant has become a gathering of many artists of the cultural base through transforming and reusing. After the transformation, various types of cultural creative industries were introduced, such as art design, animation, photography, painting, and other industries. OCT Creative Culture Park has successfully promoted the vitality of the whole region and has become one of the important cultural activities of the city. (杨敏 2014)

\section{2) Beijing 798 Art District}

798 Art District located in Dashanzi, Chaoyang District of Beijing, China. comprises a complex of 50-year-old decommissioned military factory buildings boasting a unique architectural style. After the 1990s, due to difficulty to adapt to the market economy environment, some factories are rent. Some of the artists with advanced vision found this buried treasure, and these old factories of the Bauhaus style with bright and spacious large space are suitable for their artistic creation and art exhibition. Meanwhile, it displayed cultural elements, for a strong revolutionary atmosphere slogan "Chairman Mao Long live" was retained, which was symbolized as the witness of that era.

798 Art District is mostly zigzag cast-in-place shell structure and high indoor space. These buildings are made up of the same unit simply repeated arrangement. Each unit ventilation and lighting conditions are the same. More than 6meters height provides more space for the transformation. Many avant-garde artists are obsessed with this mixed state. Thus, when they reuse these old plants, they either keep the originals of the buildings, pipes and abandoned lines, or transform them with install lights or adding glass to create a nostalgic artistic atmosphere.

\section{Implications from the cases' studies}

The transformation and reuse of the old industrial buildings are of great significance because it not only can make full use of existing resources in the city to save investment, which is a major strategy for building a conservation-oriented society, but also can continue the city context and enrich urban organic update.

Based on the analysis above, the old industrial building reconstruction and reuse design are inseparable from the following points from theoretical research to design methods:

(1) The design should reflect a sense of time and reflect the historical context inheritance relationship through the collision of old and new material; Focus on the historical continuity of urban renewal and the sustainability of people's psychological feelings(赵和生, 2005).

(2) The design should reflect the principle of sustainable development and the design methods of ecological energy-saving, save the traditional energy sources such as coal and oil regarded as the common sense of non-renewable energy and rational utilization of renewable energy 
such as clean alternative energy sources such as the solar energy, biomass energy, wind, and geothermal energy.

(3) Before the design, it needs to do all aspects of the assessment work. After the completion of the design, several benefits should be considered, such as the maximization of comprehensive benefit and the balance of social benefit, ecological benefit, and economic benefit. Meanwhile, the design should avoid the simple pursuit of economic benefits of short-term phenomenon.

In the process of urbanization, the transformation and renewal or reuse of old industrial buildings reflect the great significance in the city's sustainable development.

Most of those old buildings carry rich cultural elements though they are old in the development of city view. Therefore, this paper attempts to discuss the reuse of those old buildings in a viewpoint of sustainable renewal.

With the deepening understanding of the old industrial buildings' value, the theory and practice of the transformation and reuse of old industrial buildings have been maturing. The center of the transformation and reuse of old industrial buildings has gradually increased from a few developed cities to a large number of small and medium-sized developing cities. We believe that with the help of the more scientific and reasonable technology, the sustainable renewal or reuse and transformation of the old buildings in China will enter the more healthy development state.

\section{References}

[1]. Ye, Y. B. (2005). Integration and symbiosis: The old building reuse and study on the relationship between the old and new. [J]. Huazhong University of Science and Technology Press.

[2]. Ye, Y. B. and Liu, X. (2005).The advantages and constraints of the transformation and reuse of the old industrial buildings.35(6). p. 35-38.

[3]. 黄排雯.面向未来的城市规划和设计一可持续性城市规划和设计的理论及案例分析 (M]. 北京: 中国 建筑工业出版社, 2004, p11.

[4]. 李亦哲, 郭卫宏. 浅谈旧工业建筑单体改造与再利用的方法 $[\mathrm{J}]$. 《广东土木与建筑》, 2015

[5]. 杨敏.城市旧工业建筑改造的策略研究 [J].《现代城市研究》, 2014

[6]. 赵和生.城市规划与城市发展南京[M]:东南大学出版社, 2005:p209. 